\title{
Calibrating the duration and timing of the Messinian salinity crisis in the Mediterranean: linked tectonoclimatic signals in thrust-top basins of Sicily
}

\author{
R. W. H. BUTLER ${ }^{1}$, E. McCLELLAND ${ }^{2}$ \& R. E. JONES ${ }^{1,3}$ \\ ${ }^{1}$ School of Earth Sciences, The University of Leeds, Leeds LS2 9JT, UK (e-mail: butler@earth.leeds.ac.uk) \\ ${ }^{2}$ Department of Earth Sciences, The University of Oxford, Parks Road, Oxford OX1 3PR, UK \\ ${ }^{3}$ Present address: BP Exploration Operating Company, Chertsey Road, Sunbury-upon-Thames, Middlesex \\ TW16 7LN, UK
}

\begin{abstract}
The Messinian 'salinity crisis' which affected the Mediterranean represents one of the most dramatic examples of base-level fluctuation known in the geological record: an amplitude of perhaps $2 \mathrm{~km}$ within a stage with a duration of less than $2 \mathrm{Ma}$. Deposits within the Caltanissetta Basin of central Sicily are used to calibrate the duration and timing of these fluctuations. Two successions of evaporites termed 'First Cycle' and 'Second Cycle', are separated by an inter-regional unconformity. The first cycle is regionally regressive while the second is transgressive. Chronostratigraphic calibration of these deposits has been provided by a linked magnetostratigraphic, structural and sedimentological study. The regression was protracted. The earliest evaporites in our study accumulated early in Chron C3Ar (pre 6.88 Ma) and the youngest accumulated late in chron C3An (post 6.0 Ma). During this interval the basinward shift in coastline was $70 \mathrm{~km}$ and in vertical section implies a relative fall in sea level at $0.3-0.4 \mathrm{~m} \mathrm{ka}^{-1}$. Lowstand probably finally occurred at 5.8-5.5 Ma. Transgression, marked by accumulation of the 'second cycle' deposits, which all record reversed magnetizations (C3r), apparently occurred far more rapidly (200 ka), prior to the return to 'normal' marine conditions in the central Mediterranean late in Chron C3r. Local rates of tectonic deformation are relatively slow within the thrust belt which underlies the Caltanissetta Basin. Therefore, it is likely that the timing and rates of the Messinian 'salinity crisis' on Sicily are generally applicable to other basins in the region and help to underpin rates of climate change within this part of the Neogene.
\end{abstract}

Keywords: Mediterranean, Messinian, Sicily, syn-tectonic sedimentation, climate change.

The Messinian 'salinity crisis' which affected the Mediterranean is one of the most dramatic examples of regional environmental change outside the polar regions in Neogene times. Its origins lie in the interaction between a slowly evolving palaeogeographic framework driven by plate tectonics and a eustatic fall in sea level linked with global cooling. The discovery of thick evaporite successions beneath the floor of the Mediterranean, particularly as part of the Deep Sea Drilling Project in the early 1970s (e.g. Hsü 1972; Hsü et al. 1978), led to the suggestion that these basins were almost completely desiccated with local base levels several kilometres below normal sea level. Understanding the timing and duration of this, apparently Mediterranean-wide lowstand, and the timescales for the regressions and transgressions is critical in developing models for this type of environmental change and for calibrating depositional models for evaporite accumulation. The duration of the Messinian stage, conventionally measured at just $1.5 \mathrm{Ma}$ (e.g. Harland et al. 1990), clearly makes the 'salinity crisis' a prime example of rapid change. However, conventional biozonal stratigraphy is of limited use in understanding the timing of these changes in detail because normal marine conditions only provide a bracket on the total history of the crisis. Consequently, modern stratigraphic methods must be adopted to calibrate the crisis in detail. Here we present the results of an integrated magnetostratigraphic and sedimentological study which, allied to the vestigial faunal data, permit a high resolution calibration of the 'salinity crisis'. We use our approach to test sequence stratigraphic models for the deposition of Messinian strata in thrust-top basins on Sicily and then use these results to discuss their implications for Mediterranean palaeoceanographic evolution.

\section{Geological setting}

Messinian strata on Sicily (Fig. 1) represent the greatest accumulations of late Neogene evaporites in the circumMediterranean region (Decima \& Wezel 1973). The following notes outline the salient features of these deposits. Further details are provided by recent publications mentioned below. The evaporites of central Sicily accumulated within a series of thrust-related synclines (Butler et al. 1995) collectively termed the Caltanissetta Basin (Ogniben 1957). The thrust belt consists of a major basal detachment (Bianchi et al. 1989) and widely spaced thrust-related folds above (Butler \& Grasso 1993). Thrust-related synclines are markedly periclinal and hence it was the structural geometry of these sub-basins that controlled the evaporite distribution and facies (Butler et al. 1995). Local deformation rates during the late Neogene were very slow. Limb-tilt rates have been recorded from stratigraphic relationships at $1^{\circ} 28 \mathrm{ka}^{-1}$ with individual fold structures shortening at less than $0.2 \mathrm{~mm} \mathrm{a}^{-1}$ (Butler \& Lickorish 1997). Therefore, across the Caltanissetta Basin as a whole, rates of relative sea-level change dominantly reflect those of eustasy (e.g. Jones 1996), although clearly modified from place to place by local folding. 


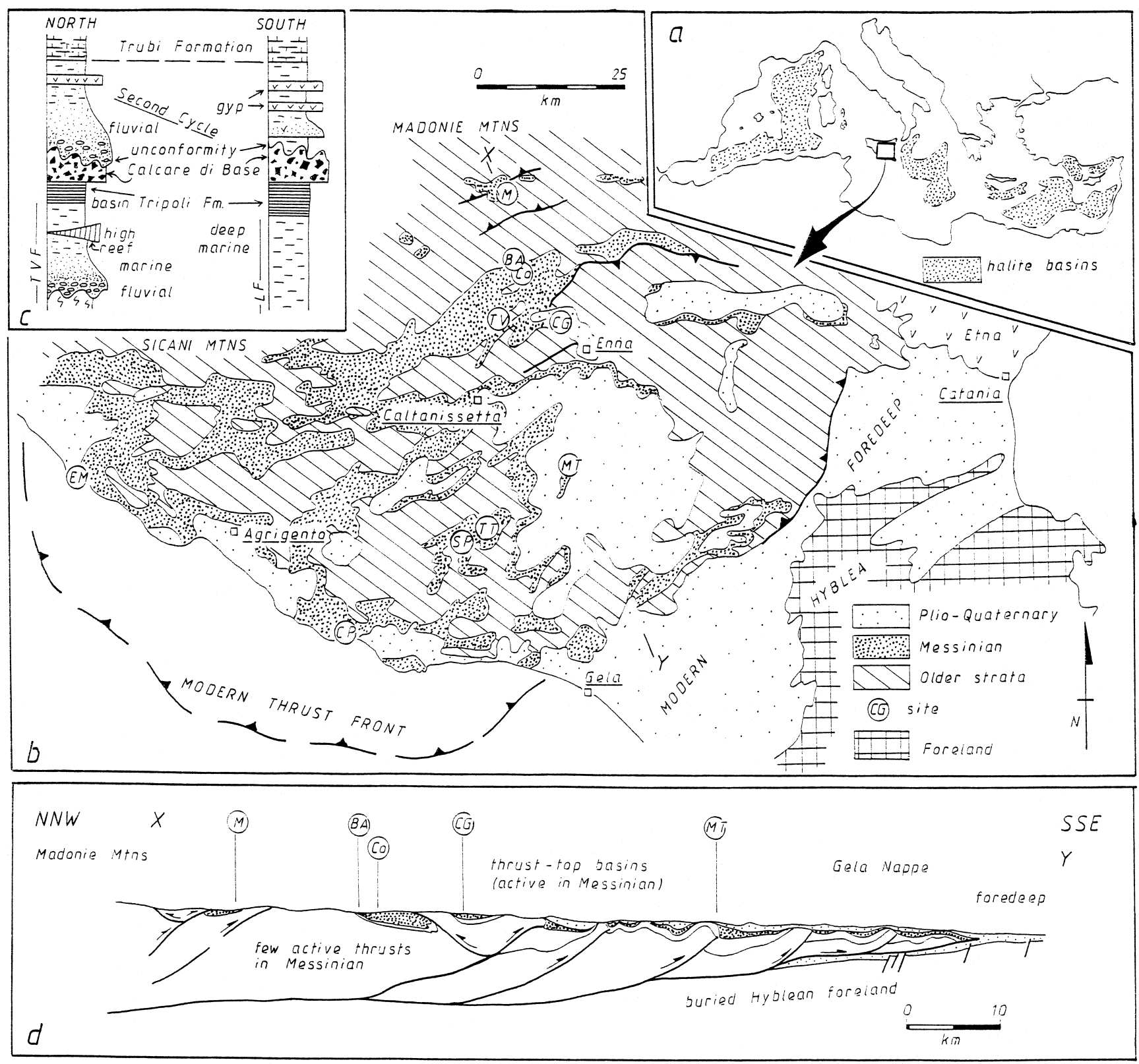

Fig. 1. (a) Location of Sicily within the Mediterranean and the location of (b). (b) Map of the Caltanissetta Basin, showing sample sites and the distribution of Messinian basins, together with the section line (X-Y) of (d). The magnetostratigraphic sites mentioned in this paper are located: EM, Eraclea Minoa; Co, Corvillo; M, Madonnuzza; BA, Balza di Arredula; TV, Torrente Vacarizzo; CG, Contrada Gaspa; MT, Monte Torre; SP, Serra Pirciata; CP, Castro di Palma. (c) Simplified representation of stratigraphic units in the Caltanissetta Basin. No vertical scale is intended (thicknesses highly variable). The northern section is based on the Corvillo Basin area (locations Co, CG and BA on b); the southern section is based on the Agrigento area (CP and EM of b). TVF, Terravechia Formation (subaerial and shallow marine sands grading up into marine clays, with or without patch reefs on structural highs. This passes up into Tripoli Formation laminites only in some sub-basins). LF, Licata Formation (marine clays accumulated under substantial bathymetry, ubiquitous passage up into Tripoli Formation). The Calcare di Base passes laterally into gypsum, halite and potash salts in restricted sub-basins. The Second Cycle (upper Messinian) units include detrital gypsum and siliciclastic sands (proximal and subaerial in North, distal and subaqueous in the South) together with primary selenitic gypsum beds. All locations, where preserved, pass up into Trubi Formation (Pliocene). (d) Sketch cross-section across the Caltanissetta Basin (vertical=horizontal scales: modified from Butler et al. 1995; Butler \& Lickorish 1997).

For much of southern central Sicily, in the distal parts of the thrust belt, the Messinian evaporites are underlain by diatomaceous laminites of the Tripoli Formation which pass up transitionally from marine clays and muds of the Licata Formation (Fig. 1c). The upward transition into the evaporites and microbial lime muds, reflects a systematic shoaling up-section together with increasing palaeoenvironmental restriction (Pedley \& Grasso 1993). Thus the deposition of the earliest evaporites was linked with regression. In the northern and central parts of the Caltanissetta Basin the sediments 


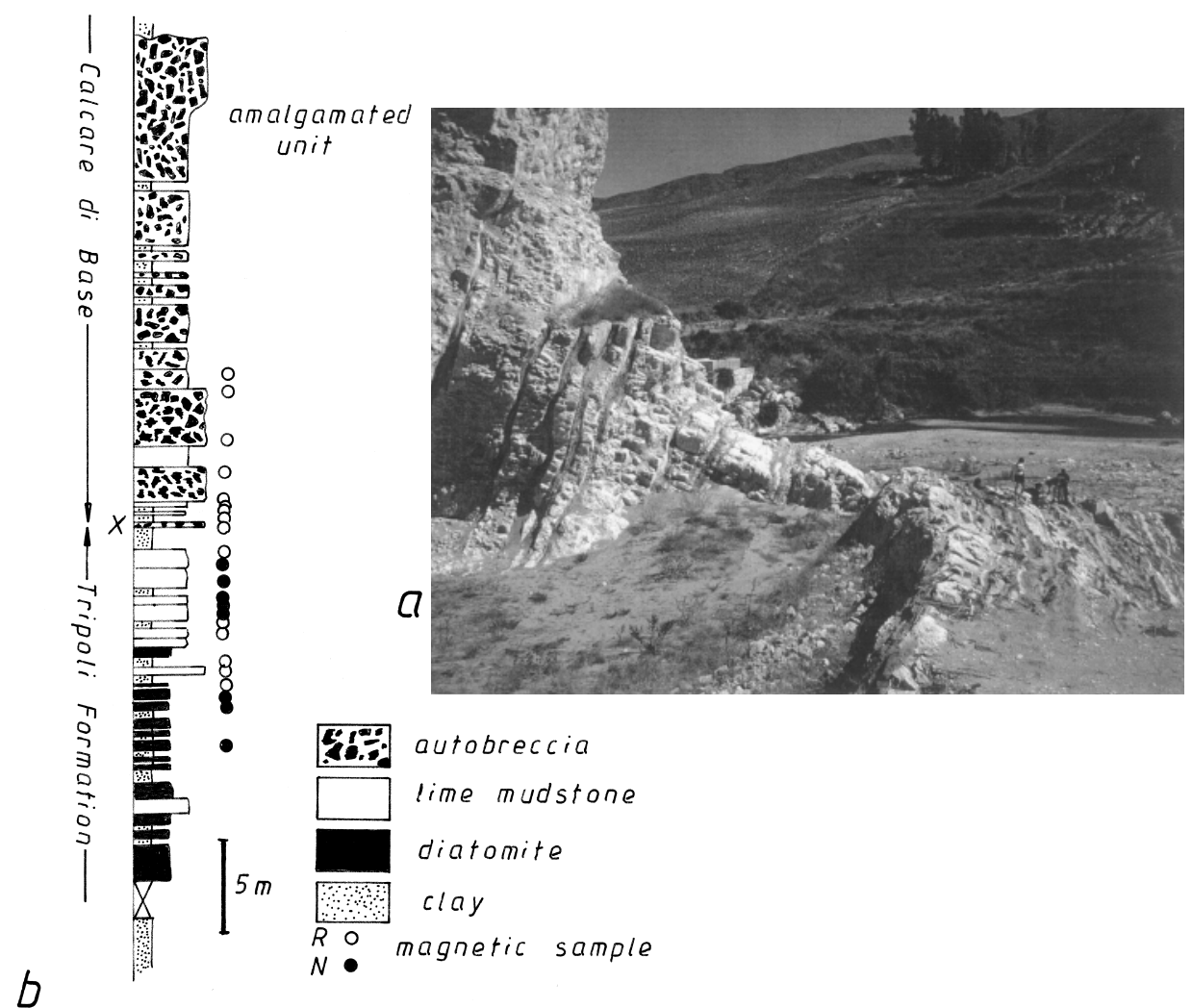

Fig. 2. Example of the transition up into the Calcare di Base, from Serra Pirciata. (a) photograph of the section, looking east. The section is subvertical and youngs to the $\mathrm{N}$ (left). Geologists on the outcrop give the scale. (b) Sketch $\log$ through the section with summary of magnetostratigraphic results (modified after Pedley \& Grasso 1993 and Butler et al. 1996). $\mathrm{X}$ is the basal autobrecciated bed - the base of the Calcare di Base in this section. which underlie the evaporites include reefs (Grasso \& Pedley 1988), subaerial clastics (Butler \& Grasso 1993) and a mappable river system which fed sediments across the array of thrust-top basins in Late Tortonian times (Jones 1996; Jones \& Grasso 1995). These sediments constitute the Terravecchia Formation which is interpreted as the proximal equivalent to the Licata Formation in southern Sicily (Fig. 1c). All these Late Tortonian-Early Messinian sediments pass up into marine clays indicating that the 'salinity crisis' was preceeded by a regional transgression. This correlates with highstands TB3.3 and TB3.4 on the sea-level curve of Haq (1991). Nevertheless, the legacy of Late Tortonian thrust-top sedimentation was a palaeobathymetric profile that regionally changed from relatively shallow water in the north to deep water in the south across the Caltanissetta Basin (Butler et al. 1995). Although in detail the seabed geometry was modified by local folding, the regression which accompanied the accumulation of the earliest evaporites on Sicily occurred across this bathymetric profile.

Messinian evaporites on Sicily are found in two stratigraphic groups separated by an inter-regional unconformity (Decima \& Wezel 1973). These groups are traditionally named the 'First' and 'Second' cycle, although the use of the term 'cycle' has no sequence stratigraphic connotations. The early, 'First Cycle', evaporites include a wide range of evaporite facies, including potassium salts. In general these more soluble salts are preserved within synclines. In contrast the higher structural levels represented by the crests of anticlines, hosted an extensive carbonate body termed the Calcare di Base (Ogniben 1957). This name is a misnomer for the carbonate is the lateral equivalent to evaporites within adjacent basins, as indicated not only by field relationships (Pedley \& Grasso 1993) but also the presence of pseudomorphs after halite and gypsum within the carbonates. In general, the Calcare di Base is a microbial lime mudstone within which evaporite minerals grew. It commonly shows bed-by-bed autobrecciation and preservation of palaeokarst infilled by the next youngest lime mudstone bed (Pedley \& Grasso 1993). This linked depositional and early diagenetic history places the Calcare di Base close to a palaeo-coastline.

The First Cycle evaporites record virtually no detrital input, apart from locally derived, slumped and reworked material on the flanks of some anticlines. In contrast, above the interregional unconformity, the Second Cycle evaporites include thick detrital successions (Decima \& Wezel 1973; Butler et al. 1995). The sudden influx of detrital material presumably reflects increased run-off compared with that during the deposition of the First Cycle. Further details are provided by Keogh \& Butler (this volume). The Second Cycle has a regionally transgressive behaviour, as indicated by the facies evolution at individual sites and systematic onlap (Butler et al. 1995). Evaporitic deposition and much of the detrital input ended by the Pliocene, a time marked by the widespread deposition of chalks of the Trubi Formation (e.g. Kastens \& Mascle 1990; Fig. 1c).

To summarize, the Messinian evaporites in the Caltanissetta Basin developed during a regressive-transgressive cycle in sea-level. These sediments accumulated in thrust-top basins which, because of the pre-evaporitic sediments and their palaeogeography, are inferred to have formed a palaeobathymetric ladder of sub-basins from north to south. It was on the basis of these relationships that Butler et al. (1995) predicted diachroneity in the onset of evaporite accumulation across Sicily - a prediction that is tested by the study reported here. 


\section{Stratigraphic methods}

The stratigraphic succession from marine to shallow-water and emergent sediments that marks the onset of deposition of the Calcare di Base at individual sites is ideal for charting the migration of the Messinian coastline across Sicily. This transition is exemplified from the southern part of the Caltanissetta Basin by the Serra Pirciata section (Fig. 2; Butler et al. 1996). The lower part of the section contains diatomaceous laminites and lime muds interbedded with clays which host abundent planktonic fauna including keeled foraminifera indicative of water depths in excess of $200 \mathrm{~m}$ (e.g. Cita 1975). In common with all other sections through the Tripoli Formation (Pedley \& Grasso 1993), these lithologies are rhythmically interlayered. The depositional cycles have been inferred to correlate with precession cyclicity (Krijgsman et al. 1994). Lithological cyclicity is matched by cycles of faunal diversity (Pedley \& Maniscalco this volume). The facies passes up into the Calcare di Base. Diatomaceous laminites become less common as the importance of lime muds increases and the faunal diversity decreases. The upper part of the section contains massive beds of autobreccia with local pseudomorphs after gypsum and halite. We interpret the autobreccia as reflecting very early diagenesis, principally formed by the dissolution of evaporitic minerals and the replacement by microbial limestones. The lower autobreccia units are up to $1 \mathrm{~m}$ thick and are capped by lime muds and thin clays which fill palaeokarstic cavities. Thus autobrecciation occurred immediately after the accumulation of individual beds, involving flushing of meteoric water at or close to sea level. Pedley \& Grasso (1993) interpret these depositional/diagenetic cycles as reflecting regular cyclic variations in sealevel, presumably with amplitudes in the order of $10-20 \mathrm{~m}$. Autobrecciation may be used as a proxy for nearshore to emergent conditions.

The transition described above, from open marine to coastal sediments, is ideally suited for charting the Messinian regression. The aim of our study was to calibrate the onset of marginal marine deposition at a variety of sites across the Caltanissetta Basin, as indicated by the oldest occurrence of autobreccia within the transition up into the Calcare di Base. The more northern sites do not contain diatomites in the pre-evaporitic strata (Pedley \& Grasso 1993; Butler et al. 1995). Also, many sections did not record complete magnetostratigraphies. However, bedding within the Calcare di Base is generally defined by cyclic deposition and autobrecciation.

\section{Magnetostratigraphy}

A variety of sites across the Caltanissetta Basin were selected for magnetostratigraphy study. Of these just five provided near-continuous sections through the basal transition into the Calcare di Base. Magnetostratigraphies were constructed for these sites, together with a further six sections through the Calcare di Base alone.

Over 1400 palaeomagnetic samples have been fully demagnetized using both AF (alternating field) and thermal demagnetization methods and analysed to identify the magnetic components. All magnetizations were measured during the demagnetization procedure using a Cryogenic Consultants GM400 cryogenic magnetometer at Oxford University. The total NRM intensity was very weak (from $0.6 \mathrm{~mA} \mathrm{~m}^{-1}$ to $0.01 \mathrm{~mA} \mathrm{~m}^{-1}$ ) for all samples, whether from Tripoli, Calcare di Base or Second Cycle evaporites. Most samples carry a significant magnetic overprint directed along the recent Earth's
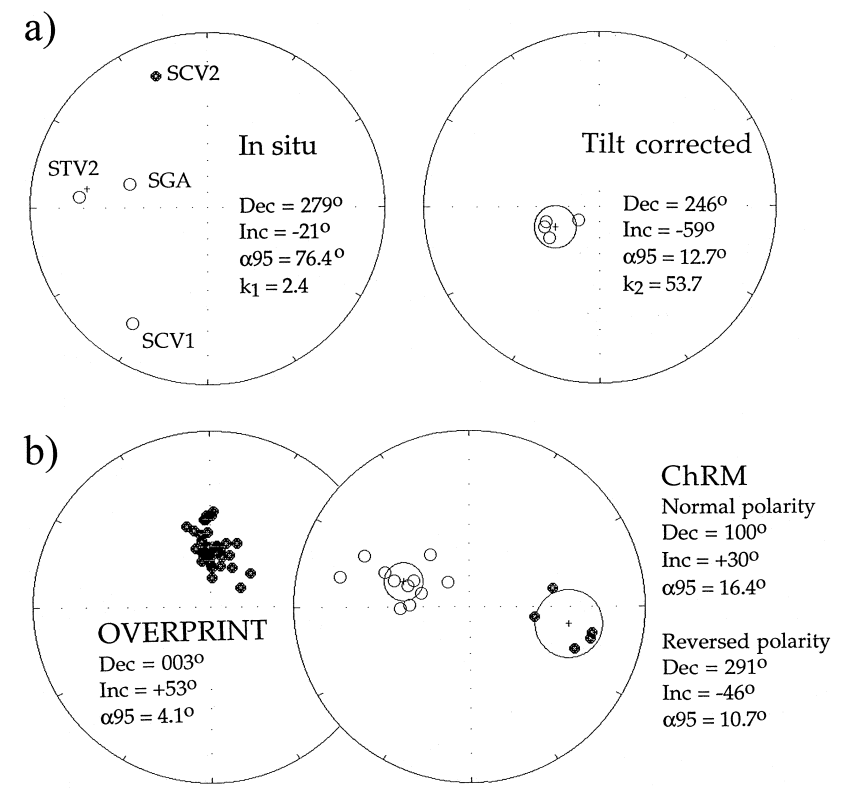

Fig. 3. Examples of geometric tests for primary remanence dating from deposition and the early diagenetic history of sediments. Palaeomagnetic data are plotted on equal area projections. (a) Fold test applied to Calcare di Base sites. Applying tilt correction to magnetic directions from four sites around a fold structure at Contrada Gaspa (location CG on Fig. 1) produces statistically significant improvement in grouping compared to in situ directions. $N=4 ; k_{2} / k_{1}=22.3>4.28$ for significance at $95 \%$ probability.

(b) Reversal test applied to directions from Contrada Gaspa; normal and reversed directions are antiparallel within error.

magnetic field. This component is removed by heating up to $275-300^{\circ} \mathrm{C}$ or by applying AF fields of $30-50 \mathrm{mT}$. Our interpretation of these magnetic results is that the magnetic overprint is carried by an iron sulphide, while the higher stability characteristic remanence (ChRM) is carried by magnetite. Further experimental details of two sites (SP and CP on Fig. 1) are provided by McClelland et al. (1996) although the stratigraphic interpretations of this earlier study are superceded by the current paper.

The studied Messinian strata on Sicily are characterized by extremely weak primary remanences. The dominant magnetic component is the modern normal polarity field. Consequently, in flat-lying strata, it is difficult to isolate primary remanences when they record normal directions. An advantage of working in tectonised basins is that tectonic tilts, developed after acquisition of the primary remanence but before the modern overprint, permit the isolation of the two components during demagnetisation experiments. Folding continued through the Messinian, as indicated by angular unconformities between the First and Second cycles and by the differential accumulation of evaporites between anticlines and synclines (Butler et al. 1995).

A variety of conventional tests were performed to establish if the high stability characteristic remanences that we were able to isolate were acquired very soon after deposition. Composite fold and tilt tests show that the dominant modern normal polarity component was acquired after folding was completed, conversely the ChRMs were acquired before folding while the beds were horizontal (Fig. 3a). Furthermore, for individual sites, the normal and reversed ChRM directions are antiparallel (Fig. 3b). Thus our data survive these large-scale tests. Local conglomerate tests were possible using clasts of Calcare 
di Base within coarse detrital deposits of the Second Cycle, and indicate that the high-stability remanence predates the formation of the conglomerate. In a few localities we were able to perform local fold tests using slumps, particularly in lime mudstones. These tests show that the remanence was aquired after slumping, but probably before compaction.

Additionally, two pieces of circumstantial evidence point to primary remanence for the Calcare di Base being acquired during early diagenesis. First, in single bed autobreccia units it is possible to isolate the same primary remanence direction for different samples. Thus these remanences were acquired after local brecciation. However, the thicker autobreccia beds, formed by amalgamation of several original autobrecciated units, do not record reproducible primary remanence directions. These results are consistent with primary remanence being acquired during the initial brecciation process during karstic dissolution of evaporites and their replacement by microbial limestones. Second, in the few samples where there has been no overprint, we have attempted to identify the magnetic carrier. After dissolving the carbonate and evaporite minerals we have identifed the primary magnetic carrier to be cubic, sub-micron-sized crystals of magnetite; this too is a very good indication of primary origin from magnetotactic bacteria.

\section{Linking magnetostratigraphy with astro-stratigraphy}

For Plio-Pleistocene successions there now exists a calibrated, linked magnetostratigraphy and astrostratigraphy (Berggren et al. 1995; Lourens et al. 1996). In this, the number of depositional cycles within each magnetic reversal chron is compared with the number of cycles predicted from periodic changes in earth orbit. In general, there is excellent correlation between depositional cyclicity and precession which survives comparisons between different sites. To date this approach has not been applied successfully to the Messinian of the Mediterranean because of the incomplete nature of sedimentary successions through the 'Salinity Crisis' (e.g. Krijgsman et al. 1994). However, existing results suggest that the lithological cycles within the Tripoli Formation reflect precession cyclicity (Krijgsman et al. 1994) which presumably forced fluctuations in surface bioproductivity. The depositional/ diagenetic history of beds within the Calcare di Base reflects cyclic variations in sea level which may also reflect precession. Consequently we use these cycles to calibrate magnetostratigraphy although clearly the successions on Sicily are incomplete and cannot be traced up into the Pliocene.

Reversal patterns do not give absolute ages for sedimentary rocks, even for those parts of the geological record that has been calibrated against absolute chronology as part of the Geomagnetic Polarity Timescale (Cande \& Kent 1992, 1995). Conventionally the ambiguity of the binary nature of a magnetostratigraphic section is constrained using biozonal fauna. However, as this record is itself dependent on palaeoenvironment, its use in charting marginal marine environmental change could be misleading. Cyclic sedimentation, provided the cycles reflect orbital processes rather than local processes, offers the chance to calibrate magnetostratigraphy. Magnetic chrons are of unequal length and therefore contain different numbers of precession cycles. The expected number of precession cycles can be simply estimated by dividing the duration of each chron (Cande \& Kent 1995) by the duration of precession cycles for the late Neogene (c. 24 ka, Langereis \& Hilgen 1991;
Lourens et al. 1996). For the Messinian, the durations of the reversed chrons are particularly variable and thus provide an excellent chance for integrating the two stratigraphic methods.

In practice, the integration of magnetostratigraphy with astronomical stratigraphy based on depositional cyclicity, is likely to be difficult in tectonically active basins. Laminites and muds are highly prone to slumping and non-deposition because of slope processes operating on the ancestral sea-bed. They may also be excised by currents. Consequently in tectonically active regions, incomplete stratigraphies should be expected. Thus the number of precession cycles observed for a given magnetostratigraphic chron should generally be expected to be less than the predicted number.

\section{Results}

We present our results in the form of a magnetochronostratigraphic diagram (Fig. 4), within which the sites are organized in approximate order down the inferred palaeobathymetric profile across the thrust belt. The correlations have been produced using a number of criteria. The number of observed precession cycles must not exceed the predicted number for the length of the correlated polarity interval. Two of our sections (MT and SP on Fig. 4) contain a conformable boundary between biostratigraphically determined Tortonian age sedimentary rocks of the Terravecchia Formation and the overlying Messininan Tripoli Formation, and this broadly defines the age of the base of these sections. Our correlations of Messinian age sedimentary rocks must not overlap with welldated younger or older sediment sections from Sicily. Assuming that the observed depositional cyclicity correlates with precession, our stratigraphic calibration of Messinian sections relies on matching the observed numbers of cycles with those predicted for each chron. With reference to Fig. 4, the logged sections of magnetic and depositional cycles (central columns on the diagram) can be matched against the predicted timescale (the side columns) while honouring the rock sequence and way-up of sections. We provide the following description as a guide.

\section{General diachroneity}

The most complete magnetostratigraphic sections that we identified come from Monte Torre (MT on Figs 1 and 4) from the centre of the Caltanissetta Basin, and from Castzo di Palma on the south coast (CP on Figs 1 and 4). The first occurrence of Calcare di Base occurs in different polarity chrons for these two sites, indicating diachroneity in deposition. At Monte Torre (MT), the Calcare di Base comes within a reverse chron that also contains at least 12 depositional cycles in the underlying Tripoli Formation. The Castro di Palma site (CP) has 14 cycles in the Tripoli Formation which accumulated during a reversed chron, overlain by a further four cycles which record normal polarities before the first Calcare di Base bed. This is also normally magnetized (Fig. 4). At our other three successful magnetostratigraphic localities, the first occurrence of Calcare di Base comes within a reverse chron. At Contrada Gaspa (CG on Fig. 1) the Calcare di Base is underlain by at least nine cycles of reverse magnetized Tripoli Formation.

Within the Messinian, only two reverse chrons represent sufficient time to record more than nine precession cycles so the three reversed intervals at the top of our sections which 


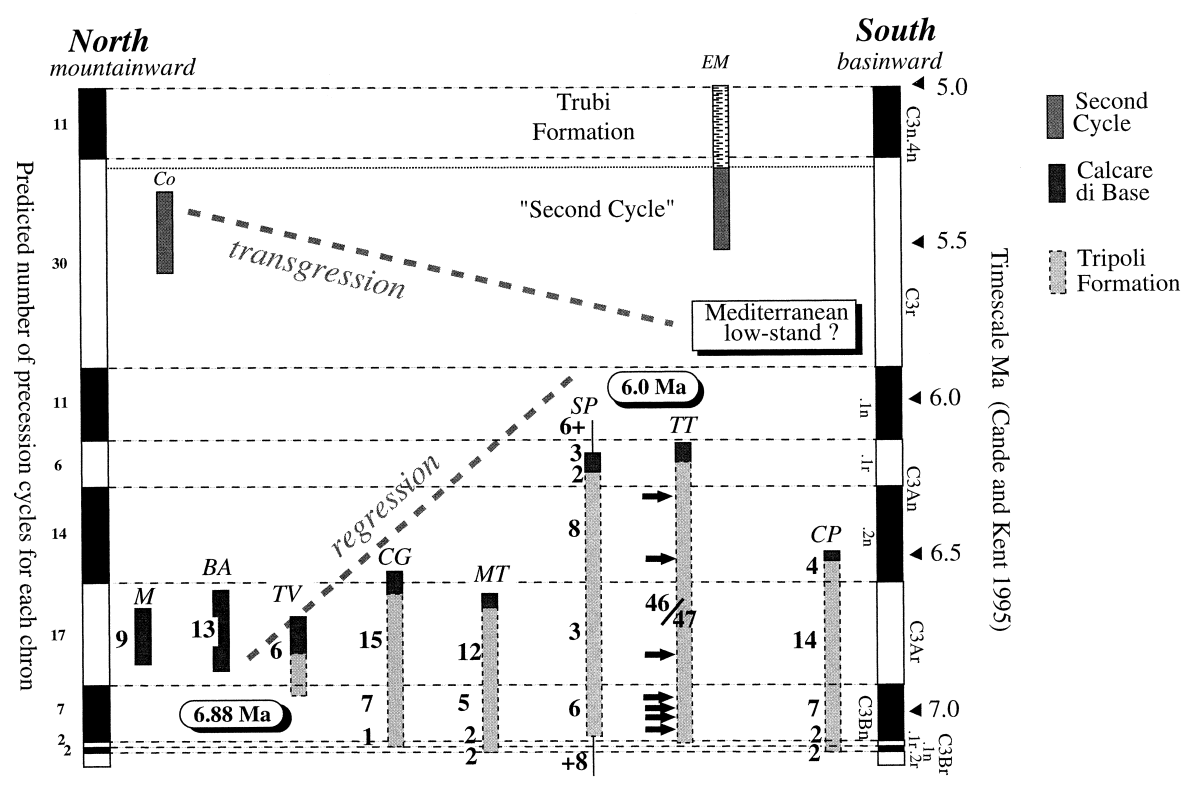

Fig. 4. Magnetochronostratigraphic diagram for Messinian strata of the Caltanissetta Basin. The bold numbers beside the columns denote the observed number of lithostratigraphic cycles, for comparison with the number expected from precession cyclicity. Locations are shown on Fig. 1. EM, Eraclea Minoa (Trubi chronostratigraphy from Langereis \& Hilgen 1991); Co, Corvillo; M, Madonnuzza; BA, Balza di Arredula; TV, Torrente Vacarizzo; CG, Contrada Gaspa; MT, Monte Torre; SP, Serra Pirciata; TT, Trabia Tallarita; CP, Castro di Palma. Note that section TT did not yield a detailed magnetostratigraphy. The arrowed levels in the log denote our only reliable magnetic data from here. The location of sites is on Fig. 1b. contain more than nine cycles must represent either Chron C3r (Late Messinian to Pliocene) or Chron C3Ar (Early Messinian). Since we have already demonstrated diachroneity in the first occurrence of the Calcare di Base, we need to look at the correlation for each section in turn, rather than assuming that one correlation can be extrapolated to each section.

\section{Monte Torre (MT on Fig. 4)}

The Monte Torre site (MT on Fig. 1) contains three reversed polarity intervals separated by two normal polarity intervals. The base of the section contains the transition from Late Tortonian clays to the Early Messinian Tripoli Formation, constraining this reversal sequence to be Early rather than Late Messinian in age. This correlation is supported by the number of sediment cycles in each polarity zone. We find 12 cycles plus the basal Calcare di Base in Chron C3Ar where 17 cycles are predicted, five cycles in Chron $\mathrm{C} 3 \mathrm{Bn}$ where seven are predicted, and two cycles each in Chrons $\mathrm{C} 3 \mathrm{Br}$.1r and $\mathrm{C} 3 \mathrm{Br}$.1n where two are predicted in each of these chrons. Our precession cyclicity calibration for Monte Torre suggests that coastal environments were being established at this site towards the end of Chron C3Ar (c. 6.6 Ma; Cande \& Kent 1995).

\section{Contrada Gaspa (CG on Fig. 4)}

Further north at Contrada Gaspa (CG on Figs 1 and 4), the top of the section includes a normal polarity succession in the Calcare di Base. This normal polarity zone precludes a correlation of the reversed interval at the top of the Tripoli Formation in this section with Chron $\mathrm{C} 3 \mathrm{r}$, since such a correlation would mean that the normal zone was Chron C3n.4n, in the Pliocene. If the Gaspa section was this young the Calcare di Base here would be coeval with Trubi Formation deposition on the south coast of Sicily. We consider this correlation highly unlikely since the Second Cycle of evaporites which post-date the Calcare di Base were deposited before the Trubi Formation (Fig. 1c). The alternative is that the nine reversed cycles at Contrada Gaspa come from Chron C3Ar.
This correlation is supported by the nine cycles with reverse magnetisation overlying a palaeomagnetic data gap spanning eight cycles, underlain by five normal cycles and one reversed. There are 20 cycles in the reverse-datagap-normal package which matches the predicted number of 24 cycles for $\mathrm{C} 3 \mathrm{Ar}$ and Chron C3Bn combined. Thus our calibration for Gaspa indicates that this site was in a coastal setting near the end of Chron C3Ar (c. 6.5 Ma; Cande \& Kent 1995).

\section{Castro di Palma (CP on Fig. 4)}

The Castro di Palma site (CP on Figs 1 and 4) has 14 cycles within the Tripoli Formation which accumulated during a reverse chron, overlain by a further four cycles which record normal polarities before the first Calcare di Base bed which is also normally magnetized. As at the Contrada Gaspa section (CG on Fig. 4), this succession could fall within Chron C3r but again this places the onset of evaporite deposition within the Pliocene. Consequently we follow the same correlation as for Contrada Gaspa. However, the first Calcare di Base bed at Castro di Palma falls at least four precession cycles up into Chron C3An.2n (c. 6.44 Ma; Cande \& Kent 1995).

\section{Serra Pirciata and Trabia Tallarita (SP and TT on Fig. 4)}

The Serra Pirciata section (SP on Figs 1 \& 4; Butler et al. 1996) contains two pairs of normal-reversed polarity units. The top part of the diatomite-lime mudstone package contains slumps and apparent stratigraphic omissions. Finding the chronostratigraphic position of this section is thus problematic (e.g. Butler et al. 1996). However, another much more complete stratigraphic section (Trabia Tallarita, TT on Fig. 4), which contains a conformable boundary between Tortonian age sedimentary rocks of the Terravaccia Formation and the overlying Messininan Tripoli Formation, was sampled about $2 \mathrm{~km}$ from Serra Pirciata in the same basinal structure. The recovery of magnetic directions from Trabia Tallarita was much poorer than from Serra Pirciata, but we have been able to cross-correlate between the two sections to constrain their age. There are only 23 
depositional cycles of Tripoli Formation at Serra Pirciata, and the base of the autobrecciated units lies within a reversed chron. It is preceded by two normal and one reverse chron recorded within 16 cycles. At least seven cycles of Tripoli Formation lie between the lowest normal interval and the Terravacchia Formation, but these did not yield palaeomagnetic directions. On its own, the depositional cycle content of these reversals is insufficient to distinguish between two stratigraphic hypotheses for the section. The top of section could possibly lie within the base of Chron C3r. This would make the onset of Calcare di Base deposition almost $600 \mathrm{ka}$ younger than any other of our sites. The other possible correlation is with the base of the Calcare di Base within Chron C3An.1r, which would put the lowest normal interval in the Tripoli Formation at Serra Pirciata in C3Bn, in line with our correlation for the other sites.

The sediment cyclicity information from the nearby Trabia Tallarita site (TT on Fig. 4) allows us to differentiate between the two correlations. At Trabia Tallarita there are 46 cycles in the Tripoli Formation above the conformable boundary with the underlying sandstones and clays of the Terravecchia Formation. The lime muds and limestones of the overlying Calcare di Base are reverse magnetized as at Serra Pirciata. The Early Messinian correlation for Serra Pirciata would predict a total of 38 cycles within the Tripoli Formation in Chrons $\mathrm{C} 3 \mathrm{Bn}, \mathrm{C} 3 \mathrm{Ar}$, and C3An.2n, there are two reversely magnetized Tripoli cycles in the top Chron C3An.1r, and a further seven cycles underlie Chron C3Bn above the Tortonian Terravecchia Formation, making a predicted total of 47 Tripoli cycles. This fits very well with our obseration of 46 Tripoli cycles in Trabia Tallarita. Furthermore the magnetic polarity of the few samples in the Trabia Tallarita section which yielded primary magnetic directions (arrowed sites on the TT column in Fig. 4) also fits well with this cross-correlation with the Serra Pirciata section. Normal magnetized remanence occurs in cycles 11, 12, 13 and 14 interpreted as Chron 3Bn; reversely magnetized remanence in cycle 19 which we interpret as Chron 3Ar; and normally magnetized remanence in cycles 34 and 40 which we interpret as Chron C3An.2n.

Our calibration at Serra Pirciata thus places the base of the Calcare di Base within Chron C3An.1r (6.13-6.27 Ma; Cande \& Kent 1995). With at least nine Calcare di Base cycles preserved at this site, the youngest evaporites at Serra Pirciata must date at about 6.0 Ma. The final test of this calibration would be the presence of normal primary remanence directions in upper strata of the Calcare di Base, for this age falls within normal Chron C3r.1n. However, these composite autobreccia beds do not record reliable palaeomagnetic directions.

\section{Other Calcare di Base sites}

Apart from the four sites described above, the other sites which record the upward transition into Calcare di Base also fall within the stratigraphic range so far identified. This need not be the complete range for the onset of coastal conditions within our study area. In the northern part of the Caltanissetta Basin the Tripoli Formation and laminite facies are not present in the pre-evaporitic strata, so cycle stratigraphies cannot be erected. However, the Calcare di Base generally shows the bed-by-bed deposition-diagenetic histories characteristic of the southern outcrops. Assuming that these reflect eustatic cycles driven by precession, we can place some of our northern sites within the Geomagnetic Polarity Timescale. All our studied northern sites of Calcare di Base record reversed magnetic polarities (Fig. 4). For the Madonnuzza and Balza di Areddula sites ( $\mathrm{M}$ and $\mathrm{BA}$ on Figs 1 \& 4), the Calcare di Base records this single polarity through 9 and 13 depositional cycles respectively. Thus these sites must fall within the end Messinian Chron C3r or the early Messinian Chron C3Ar. Balza di Areddula lies within $6 \mathrm{~km}$ of Contrada Gaspa (Fig. 1), on a structural high. Thus we consider this section to fall within the earlier of the two possibilities. As such the base of this section represents our oldest Calcare di Base site, towards the base of Chron C3Ar (c. 6.88 Ma, Cande \& Kent 1995).

\section{Second Cycle sites}

In contrast with the gradual diachronous deposition of the First Cycle evaporites, the accumulation of the Second Cycle must have been much less protracted (Fig. 4). We studied several sites of which those at Eraclea Minoa and the northern part of the Corvillo Basin (EM and Co respectively on Fig. 1) gave the most complete sections. Our magnetostratigraphic studies of the clastic deposits which generally mark the base of this cycle record exclusively reversed remanences, presumably from Chron C3r. The return to 'normal' marine conditions, as recorded by the fauna and facies change to the Trubi Formation is dated, at least at Eraclea Minoa (Fig. 1), as being within a few precession cycles of the top of this chron (c. 5.3 Ma Langereis \& Hilgen 1991). Presumably it is within this chron that the low-stand within the Mediterranean occurred as did the transgression that is capped by the faunal colonization event reflected in the onset of Trubi Formation deposition and the start of the Pliocene stage. The nature of this transgression is the topic of a companion paper (Keogh \& Butler this volume).

\section{Interpretation: rates of Messinian regression}

The onset of evaporite deposition in shallow-water conditions at individual sections is reflected by the first appearance of Calcare di Base facies. This event is clearly diachronous within our study area; it occurs in both normal and reverse magnetic chrons. Calibrating these chrons against depositional cycles which are assumed to reflect precession cyclicity (Krijgsman et al. 1994) locates our oldest Calcare di Base units within Chron C3Ar. There are at least 13 cycles of Calcare di Base at one site (Balza di Areddula, BA on Fig. 4), indicating that these evaporites must have begun to accumulate no later than c. $6.88 \mathrm{Ma}$. The youngest Calcare di Base cycles that we have identified come for Serra Pirciata. Here the first appearance of the facies occurs in reverse Chron C3An.1r. There are at least nine cycles preserved here, underlain by a further two cycles of non-evaporitic laminites. Thus at this site the Calcare di Base has accumulated until at least 11 cycles above the start of Chron C3An.1r. This datum is placed at $6.27 \mathrm{Ma}$ (Fig. 4; Cande \& Kent 1995). Thus we deduce that the youngest Calcare di Base unit at Serra Pirciata dates at about 6.0 Ma.

The interpretation suggests that evaporite accumulation across the array of thrust top basins in Sicily had a history protracted over at least $800 \mathrm{ka}$. The Calcare di Base facies represents a coastal deposit and so this diachroeneity charts coastal regression. The maximum geographical separation is that between sites 'Madonnuzza' and 'Castro di Palma', a distance of approximately $70 \mathrm{~km}$. The difference in age of the lowest Calcare di Base between these sections is $12-20$ 


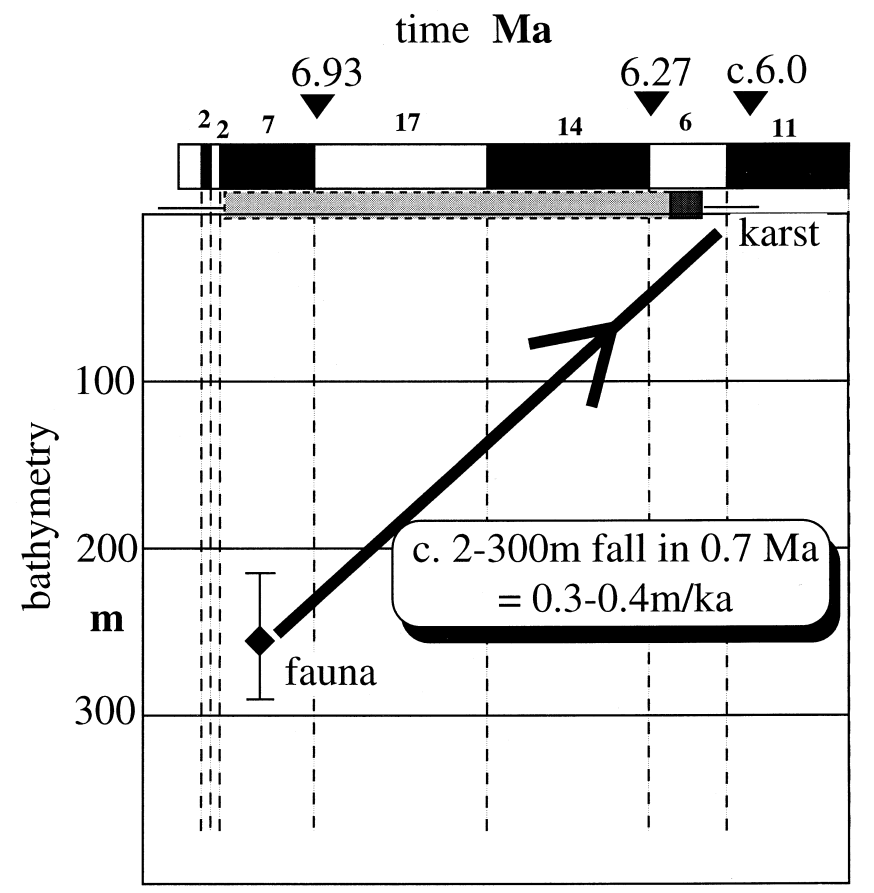

Relative sea-level fall

Serra Pirciata

Fig. 5. Bathymetry v. time graph for Serra Pirciata, showing the time-averaged rate of relative sea-level fall during the Messinian regression on Sicily.

precession cycles. This equates to a timespan of 300-500 ka. We deduce that there was a coastal shift of about $70 \mathrm{~km}$ laterally during this time.

To establish the relative sea-level fall associated with the regression we use the single site at Serra Pirciata to calibrate palaeobathymetries (Fig. 5). The Calcare di Base shows evidence for emergence. Thus the oldest Calcare di Base unit charts when this site reached sea level. The older laminates record palaeobathymetry by their faunal content. The highest occurence of keeled foraminifera, indicative of bathymetries of 200-300 m (Cita 1975), is within sediments which preserve Chron C3Bn, towards the base of the section (Butler et al. 1996). Less than $20 \mathrm{~m}$ of sediment reflects the timespan between these deep water conditions and the Calcare di Base. This stratigraphic thickness is substantially less than the estimation error for the deep-water palaeobathymetry from the fauna. Thus it appears that a $200-300 \mathrm{~m}$ fall in relative sea level at the Serra Pirciata site occurred in a timespan between 6.93 and $6.27 \mathrm{Ma}$. This corresponds to a time-averaged rate of $0.3-0.4 \mathrm{~m} \mathrm{ka}^{-1}$ (Fig. 5). Note, however, that this rate does not necessarily correspond to the rate of eustatic change because we are unable to isolate any tectonic component in this measure.

These interpretations of the regression across Sicily are incomplete because of the plunge variations within the thrusttop basins. Three sites lie along the same general axis of a sub-basin and thus chart the differential coastal shift across a single structure. Monte Torre, Serra Piciata and Castro di Palma fall along this axis (MT, SP and CP respectively on Fig. 4). Although the regional coastal shift is charted by the diachroneity in the onset of Calcare di Base facies (about ten precession cycles, c. $250 \mathrm{ka}$ ) between the two outlying sites,
Serra Pirciata falls within a plunge depression along this sub-basin. Consequently it desiccated rather later. It is interesting however, that faunal diversity within the Serra Pirciata site was very greatly reduced (Pedley \& Maniscalco this volume) when the areas marginal to the basin were experiencing coastal conditions.

\section{Discussion}

Our principal conclusion, that the deposition of evaporites across the Caltanissetta Basin was diachronous, is consistent with predictions made from sequence stratigraphy (Butler $e t$ al. 1995; Clauzon et al. 1996). However, the rates of regression across the basin are not particularly rapid. The sea-level fall which marked the onset of the salinity crisis' was protracted. During the regression, there were systematic base-level fluctuations of a few tens of metres, which correlate well with precession cyclicity in their characteristic frequency and in the amplitude of the Neogene eustatic record. In our study area on Sicily these can be identified at least until Chron C3r.1n. Thus the Mediterranean was not isolated from the world's ocean until after $6.13 \mathrm{Ma}$ (using the timescale of Cande \& Kent 1995). It will be interesting to compare this result with other marginal basins around the Mediterranean ( $c f$. Flecker \& Ellam this volume).

A corollary of our conclusion, that the onset of evaporite precipitation was diachronous between sub-basins on Sicily (Fig. 4) is that the boundaries between the main lithostratigraphic units of the First Cycle do not represent contemporaneous 'event' horizons. This is at odds with some existing hypotheses. Attempts to extend the astronomical polarity timescale through the Messinian by Krijgsman et al. (1994) have assumed a unique stratigraphic position and duration for the Calcare di Base through the entire Mediterranean. Faunal events have been hung from this datum and widely correlated (e.g. Sprovieri et al. 1996). We believe that a facies such as the Calcare di Base, which accumulated in shallow-water to emergent conditions, is most unlikely to have been deposited synchronously across different basins and across different pre-existing palaeobathymetries. Our data are certainly not consistent with such a simple hypothesis.

The sequence stratigraphic model for the 'salinity crisis' proposed by Clauzon et al. (1996) places the chief lowstand at the end of the Messinian. For these workers the Second Cycle on Sicily predates the main sequence boundary. This is not consistent with the relationship between rock units and unconformities on Sicily (Butler et al. 1995). However, their general conclusion, that the regression associated with the First Cycle evaporites was gradual and predated the chief lowstand is in accord with the sequence stratigraphic model of Butler et al. (1995) and is confirmed by the data presented here. Note that both models (Butler et al. 1995; Clauzon et al. 1996) propose that the lowstand occurred in Chron $\mathrm{C} 3 \mathrm{r}$ - although of course this interval is rather long (Fig. 4).

To conclude, the regression that marked the onset of the Messinian 'salinity crisis' on Sicily was protracted over a period of at least $800 \mathrm{ka}$. Different sediments were deposited in different palaeoenvironments during this time which, as the environments shifted during regression, accumulated diachronously betwen sub-basins. This regression was of eustatic origin and was accompanied by higher-order sea-level fluctuations on the scale of precession cycles. These palaeoclimatic signals were strongly modulated by local structures: different 
evaporite facies accumulated in different structural positions within sub-basins (Butler et al. 1995). Cycle stratigraphies vary between sites (Fig. 4). However, the overall architecture of the depositional sequence and the higher order cyclic sedimentation indicate that tectonic rates of vertical motion did not completely swamp the rates of sea-level fluctuation. These stratigraphic results are consistent with measurements of rates of thrusting within the Caltanissetta Basin (Butler \& Lickorish 1997). Although individual sites may have incomplete records of palaeoenvironmental change, the array of sub-basins carry a near-continuous record of aridity, evaporation and faunal dispersion and extinction. Future studies of environmental change would benefit from studying the full array of subbasins rather than hope for a continuous record in one vertical sedimentary section.

This research was funded as part of the Central Sicily Basins Project by the Natural Environment Research Council (GR3/8610). We thank B. Finegan for technical support together with other members of the project team (H. Lickorish, M. Grasso, R. Maniscalco, S. Keogh and M. Pedley) for support and discussions. O. R. Clausen, U. Gregersen and D. Pirrie are thanked for thought-provoking reviews.

\section{References}

Berggren, W.A., Hilgen, F.J., Langereis, C.G., Kent, D.V., Obradovich, J.D., Raffi, I., Raymo, M.E. \& Shackleton, N.J. 1995. Late Neogene chronology: new perspectives in high-resolution stratigraphy. Geological Society of America Bulletin, 107, 1272-1287.

Bianchi, F., Carbone, S., Grasso, M., Invernizzi, G., Lentini, F., Longaretti, G., Merlini, S. \& Mostardini, F. 1989. Sicilia orientale: profilo geologico Nebrodi-Iblei. Memorie della Societa Geologica Italiana, 38, 429-458.

ButLer, R.W.H. \& Grasso, M. 1993. Tectonic controls on base level variations and depositional sequences within thrust-top and foredeep basins: examples from the Neogene thrust belt of central Sicily. Basin Research, 5, 137-151.

_ \& LickoRish, W.H. 1997. Using high-resolution stratigraphy to date fold and thrust activity: examples from the Neogene of south-central Sicily. Journal of the Geological Society, London, 154, 633-643.

— - - Grasso, M., Pedley, H.M. \& Ramberti, L. 1995. Tectonics and sequence stratigraphy in Messinian basins, Sicily: constraints on the initiation and termination of the Mediterranean 'salinity crisis'. Geological Society of America Bulletin, 107, 425-439.

—, Pedley, H.M., Maniscalco, R., Grasso, M., McClelland, E. \& FineGan, B. 1996. The significance of Messinian occurrences of Globorotalia margaritae and Globorotalia puncticulata in Sicily. Terra Nova, 8, 59-64.

CAnde, S.C. \& Kent, D.V. 1992. A new geomagnetic polarity time scale for the Late Cretaceous and Cenozoic. Journal of Geophysical Research, 97, 13 917-13 951.

\& \& 1995. Revised calibration of the geomagnetic polarity timescale for the Late Cretaceous and Cenozoic. Journal of Geophysical Research, 100, 6093-6095.

CitA, M.B. 1975. Planktonic foraminifera biozonation of the Mediterranean Pliocene deep sea record. A revision. Reviews of Italian Palaeontology and Stratigraphy, 81, 527-544.

Clauzon, G., Suc, J.-P., Gautier, F., Berger, A. \& Loutre, M.-F. 1996. Alternate interpretation of the Messinian salinity crisis: controversy resolved? Geology, 24, 363-366.

Decima, A. \& Wezel, F.C. 1973. Late Miocene evaporites of the central Sicilian basin, Italy. Initial Reports of the Deep Sea Drilling Project, 13, 1234-1241.
Flecker, R. \& Ellam, R.M. 1999. Distinguishing climatic and tectonic signals in the sedimentary successions of marginal basins: an example from the Messinian salinity crisis, Eastern Mediterranean. Journal of the Geological Society, London, 156, 847-854.

Grasso, M. \& Pedley, H.M. 1988. The sedimentology and development of Terravecchia Formation carbonates (Upper Miocene) of north-central Sicily: possible eustatic influence on facies development. Sedimentary Geology, 57, 131-149.

HAQ, B.U. 1991. Sequence stratigraphy, sea-level change, and significance for the deep sea. In: Macdonald, D.I.M. (ed.) Sedimentation, Tectonics and Eustasy. Special Publications of the International Association of Sedimentologists, 12, 3-39.

Harland, W.B., Armstrong, R.L., Cox, A.V., Craig, L., Smith, A.G. \& Sмiтh, D.G. 1990. A geologic time scale 1989. Cambridge University Press.

Hilgen, F.J., Krijgsman, W., Langereis, C.G., Lourens, L.J., Santarelli, A. \& ZACHARIASSE, W.J. 1995. Extending the astronomical (polarity) time scale into the Miocene. Earth and Planetary Science Letters, 136, 495-510.

Hsü, K.J. 1972. When the Mediterranean dried up. Scientific American, 227, 26-36.

- Montadert, L., Bernoulli, D., Cita, M.B., Erickson, A., Garrison, R.E., Kidd, R.B., Mélières, F., Mueller, C. \& Wright, R. 1978. History of the Mediterranean Salinity Crisis. In: Initial Reports of the Deep Sea Drilling Project, 42, 1053-1078.

JONES, R.E. 1996. Tectonics, sedimentation and depositional sequence evolution in thrust-top basins of north-central Sicily during the late Miocene. $\mathrm{PhD}$ thesis, University of Leeds.

— \& Grasso, M. 1995. Paleotectonics and sediment dispersal pathways in North-Central Sicily during the Late Tortonian. Studi Geologici Camerti, 1995/2, 279-291.

Kastens, K. \& Mascle, J. 1990. The geological evolution of the Tyrrhenian Sea: An introduction to the Scientific Results of ODP Leg 107. In: Proceedings of the Ocean Drilling Program, Scientific Results, 107, 3-26.

Keogh, S.M. \& ButLer, R.W.H. 1999. The Mediterranean water body in the Late Messinian: interpreting the record from marginal basins on Sicily. Journal of the Geological Society, London, 156, 837-846.

Krijgsman, W., Hilgen, F.J., Langereis, C.G. \& Zachariasse, W.J. 1994. The age of the Tortonian/Messinian boundary. Earth and Planetary Science Letters, 121, 533-547.

LANGereis, C.G. \& Hilgen, F.J. 1991. The Rossello composite: a Mediterranean and global reference section for the Early to early Late Pliocene. Earth and Planetary Science Letters, 104, 211-225.

Lourens, L.J., Antonarakou, A. Hilgen, F. J., Van Hoof, A.A.M. Vergnaud, C. \& Zachariasse, W.J. 1996. Evaluation of the PlioPleistocene astronomical timescale. Paleoceanography, 11, 391-413.

McClelland, E., Finegan, B. \& Butler, R.W.H. 1996. A magnetostratigraphic study of the onset of the Mediterranean Salinity Crisis; Caltanissetta Basin, Sicily. In: Morris, A. \& TArLing, D.H. (eds) Palaeomagnetism and Tectonics of the Mediterranean Region. Geological Society, London, Special Publications, 105, 205-217.

Ogniben, L. 1957. Petrografia della Serie Solfifera Siciliana e considerazioni geologiche relative. Memorie Descrittive della Carta Geologica d'Italia, 22, $1-275$.

Pedley, H.M. \& Grasso, M. 1993. Controls on faunal and sediment cyclicity within the Tripoli and Calcare di Base basins (Late Miocene) of central Sicily. Palaeogeography, Palaeoclimatology, Palaeoecology, 105, 337-360.

_ \& Maniscalco, R. 1999. Lithofacies and faunal succession (faunal phase analysis) as a tool in unravelling climatic and tectonic signals in marginal basins: Messinian (Miocene) Sicily. Journal of the Geological Society, London, 156, 855-863.

Sprovieri, R., Di Stefano, E. \& Sprovieri, M. 1996. High resolution chronology for Late Miocene Mediterranean stratigraphic events. Rivista Italiana di Paleontologia e Stratigrafia, 102, 77-104. 